


\section{RUSSIAN ACADEMY OF SCIENCES \\ INSTITUTE FOR THE HISTORY OF MATERIAL CULTURE}

\section{B ULLETIN}

№ 10

RESCUE ARCHAEOLOGY

ST. PETERSBURG

2020 


\section{РОССИЙСКАЯ АКАДЕМИЯ НАУК \\ ИНСТИТУТ ИСТОРИИ МАТЕРИАЛЬНОЙ КУЛЬТУРЫ}

\section{БЮЛЛЕТЕНЬ}

№ 10

ОХРАННАЯ АРХЕОЛОГИЯ

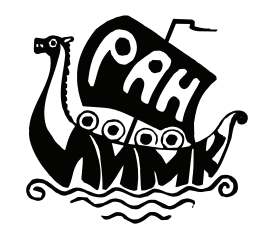

САНКТ-ПЕТЕРБУРГ

2020 
УДК 902/904

ББК 63.4

Б98

Рецензенты:

В.А. Лапшин (директор ИИМК РАН)

И. Л. Тихонов (Институт истории СПбГУ)

Ответственный редактор Н.Ф. Соловьёва

Технический редактор, оформитель С. Л. Соловьёв

Перевод: А.В. Гилевич

Корректор: А.О. Поликарпова

Бюллетень Института истории материальной культуры Российской академии наук: (охранная археология). [№] 10 / науч. ред. Н.Ф. Соловьёва;

ИИМК РАН. - СПб.: Изд-во ООО «Невская Типография», 2020. - 193 с. : ил.

Bulletin of the Institute for the History of Material Culture Russian Academy of Sciences:

(rescue archaeology). [№] 10 / ed. by N.F. Solovyova;

IHMC RAS. - SPb.: Publishing House LLC «Nevsky Printing House», 2020. - 193 pp. : ill.

ISBN 978-5-907298-13-2

Периодическое издание посвящено охранно-археологической деятельности ИИМК РАН по изучению культурного наследия России. Десятый номер бюллетеня представляет результаты археологических исследований объектов культурного наследия Санкт-Петербурга и его окрестностей, а также других регионов России, которые были осуществлены Отделом охранной археологии ИИМК РАН в сотрудничестве с другими научными, образовательными и государственными организациями в 2017-2020 гг.

Издание предназначено для историков, археологов, государственных служащих, частных предпринимателей и широкого круга читателей, заинтересованных в научной и достоверной информации об истории России и состоянии памятников ее культуры.

This periodical is dedicated to the rescuing and archaeological activities of the Institute for the History of Material Culture (IHMC) RAS in studies of the cultural heritage of Russia. The tenth issue of the Bulletin presents the results of archaeological investigations of the cultural heritage of St. Petersburg and its surroundings, as well as other regions of Russian Federation, carried out in 2017-2020 by the Department for Rescue Archaeology of IHMC RAS in collaboration with other scientific, educational and public organizations.

This publication is intended for historians, archaeologists, government employees, private entrepreneurs and a wide circle of readers interested in reliable scientific information on history of Russia and the state of the monuments of its culture.

ISBN 978-5-907298-13-2

УДК 902/904

ББК 63.4

(С) ИИМК РАН, Санкт-Петербург, 2020

(c) Отдел охранной археологии ИИМК РАН, 2020 


\title{
Археология малых городов: материалы из раскопок 2015 г. на посаде Ладоги и кожевенное дело в средневековом городе ${ }^{1}$
}

\author{
А.В. Курбатов ${ }^{2}$
}

DOI: $10.31600 / 978-5-907298-13-2-2020-180-188$

Введение. В последние годы активизировались раскопки на посаде средневековой Ладоги, т. е. вне стен Ладожской крепости и Земляного городища (Лапшин, 2018). В 2014-2015 гг. Староладожская экспедиция ИИМК РАН провела новые исследования на Варяжской улице на месте установки памятника Рюрику и Олегу (Лапшин, Миляев, 2018. С. 157 сл.). Материалы этих работ уже введены в научный оборот, за исключением кожаных изделий.

Предметы из кожи происходят с двух объектов раскопок 2015 г. на посаде древней Ладоги. Охранные раскопки велись на Варяжской улице, на месте устройства спуска к берегу Волхова от памятника основателям Русского государства князьям Рюрику и Олегу Вещему. Участок раскопок представляет береговой склон левого берега р. Волхов, возле места впадения в нее р. Ладожки. Уклон поверхности в этом месте составляет 25-30 градусов. Вторым объектом охранных раскопок была серия шурфов на посаде.

Эти раскопки на ладожском посаде можно считать, кроме всего, поиском ответа на вопрос об археологическом содержании понятия «малые города Руси», которое впервые сформулировал А. В. Куза (1983. С. 4 сл.; 1989). В 1980-е гг. исследователь относил средневековую Ладогу к основным древнерусским городам Новгородской земли (Куза, 1985. С. 88, 89). Однако к началу 1980-х гг. посады многих древнерусских городов были еще недостаточно изучены археологами, и в работах А.В. Кузы проблема «малых городов» оставалась неразрешенной. В последние десятилетия

\footnotetext{
1 Работа выполнена в рамках программы ФНИ ГАН по теме государственного задания № 0184-2019-0006 «Ремесло, торговля, международные связи Северной Руси и ее соседей».

2 191186, Санкт-Петербург, Дворцовая наб. 18. Институт истории материальной культуры РАН, Отдел славянофинской археологии ИИМК РАН. E-mail: alkurba@, rambler.ru.
}

интенсивность археологического изучения средневековых русских городов многократно возросла, что дает повод к развитию идеи А.В. Кузы. Определенный опыт такого рода предложил В.Ю. Коваль на примере своих исследований Ростиславля Рязанского (Коваль, 2014. С. 279 сл.). Среди всех признаков древнерусского города, выделенных в свое время Б.А. Рыбаковым и рассмотренных А.В. Кузой, В.Ю. Коваль обратил внимание на небольшое число специализированных ремесленных мастерских и на заметное преобладание среди населения города в золотоордынский период военно-служивого сословия. Первый из этих признаков можно рассмотреть в древней Ладоге на примере вещевых материалов, относящихся к кожевенному производству.

Состав коллекuии. Всего в коллекции из раскопок 2015 г. учтено 47 кожаных предметов, среди них 35 деталей обуви, семь обрезков от первичного и вторичного раскроя, деталь рукавицы, заплата и три мелких фрагмента неопределенных деталей. Кожаные предметы представляют широкий хронологический диапазон находок - с XII до XVIII в. (табл. 1).

Обувь. В коллекции имеются отдельные целые детали, обрезанные или оборванные фрагменты деталей, а также наборы деталей определенных видов обуви. Определимые формы обуви относятся к разным временным периодам бытования в русских средневековых городах, что определяется настоящим уровнем наших знаний. Хронологический диапазон находок определен по конструктивным и декоративным признакам моделей обуви, которые находят широкий круг аналогий в городах Восточной Европы, принадлежавших к разным землям и княжествам, входящим в политическую и культурную совокупность земель Древней Руси, Московского царства и Российской империи, и определяется рамками XII-XVIII вв. (рис. 1; 2).

К XII в. относятся: 1) предполагаемый набор детского башмака под стопу длиной 12,5-13,0 см, 
Таблиияа 1. Опись кожаных предметов на посаде Ладоге в 2015 г.

\begin{tabular}{|c|c|c|c|c|c|}
\hline $\begin{array}{l}\text { № } \\
\text { п/п }\end{array}$ & № по оп. & $\begin{array}{c}\text { Наименование и количество } \\
\text { предметов }\end{array}$ & Объект & Слой & Прим. \\
\hline 1 & 4 & $\begin{array}{c}\text { Набор мягкого башмака: } \\
\text { детали верха }-2, \text { подошва }-1\end{array}$ & Шурф 2, кв. 2, ур. 191 & Щепа с навозом & \\
\hline 2 & 6 & Подошва мягкого башмака - 1 & $\begin{array}{c}\text { Раскоп на Варяжской ул., } \\
\text { кв. } 1 \text {, пл. } 6\end{array}$ & Щепа & \\
\hline 3 & 770 & $\begin{array}{c}\text { Голенище во вторичном } \\
\text { использовании }-1, \text { головка } \\
\text { с поднарядом }-6, \text { фр-т } \\
\text { неопред. деталей }-3, \text { подошва } \\
\text { с подметкой }-2, \text { поршень }-1\end{array}$ & $\begin{array}{c}\text { Там же, кв. 62-63, } \\
\text { заполнение колодца }\end{array}$ & & 03.10 .2015 \\
\hline 4 & 815 & $\begin{array}{c}\text { Подошва }-1, \text { карман } \\
\text { задника }-1\end{array}$ & $\begin{array}{c}\text { Там же, заполнение } \\
\text { сруба } 1, \text { кв. } 20\end{array}$ & & 03.10 .2015 \\
\hline 5 & 847 & Фр-т носка подметки - 1 & Там же & $-631--662$ & \\
\hline 6 & 852 & $\begin{array}{c}\text { Заплата - } 1 \text {, деталь верха } \\
\text { башмака }-1\end{array}$ & Там же, кв. 25, пл. 7 & -717, щепа & \\
\hline 7 & 874 & Подошва сапога - 1 & Там же & -720, щепа & \\
\hline 8 & 883 & Обрезки втор. - 2 & Там же & $\begin{array}{c}\text {-708, щепа под } \\
\text { дерев. конструк- } \\
\text { цией }\end{array}$ & \\
\hline 9 & 894 & Обрывок кожи - 1 & Там же, яма 9 & & \\
\hline 10 & 965 & Фр-т детали верха обуви -1 & Там же, кв. 45, пл. 7 & $\begin{array}{c}\text { Коричн. гумус } \\
\text { с щепой }\end{array}$ & \\
\hline 11 & 970 & $\begin{array}{c}\text { Мелкие фр-ты деталей } \\
\text { обуви (?) }-2\end{array}$ & Там же, кв. 25, пл. 7 & Щепа & \\
\hline 12 & 1229 & $\begin{array}{c}\text { Набор подпяточных } \\
\text { подкладок }-3, \text { подметка }-1 \text {, } \\
\text { обрезок от раскроя }-1, \text { фр-т } \\
\text { подошвы }-1\end{array}$ & $\begin{array}{c}\text { Там же, кв. кв. 62-63 } \\
\text { Заполнение колодца }\end{array}$ & Щепа с навозом & \\
\hline 13 & 1230 & Обрезки раскроя - 3 & Там же & То же & \\
\hline 14 & 1235 & $\begin{array}{c}\text { Детали верха обуви }-2, \phi p-т ~ \\
\text { подошвы }-1\end{array}$ & Там же & То же & \\
\hline 15 & 1236 & $\begin{array}{c}\text { Фр-ты головок }-1, \text { деталь } \\
\text { рукавицы }-1\end{array}$ & Там же & То же & \\
\hline 16 & 1237 & Набор деталей задника - 3 & Там же & То же & \\
\hline 17 & & Фр-т подошвы - 1 & Там же, кв. 5, пл. 7 & Гумус с щепой & \\
\hline
\end{tabular}




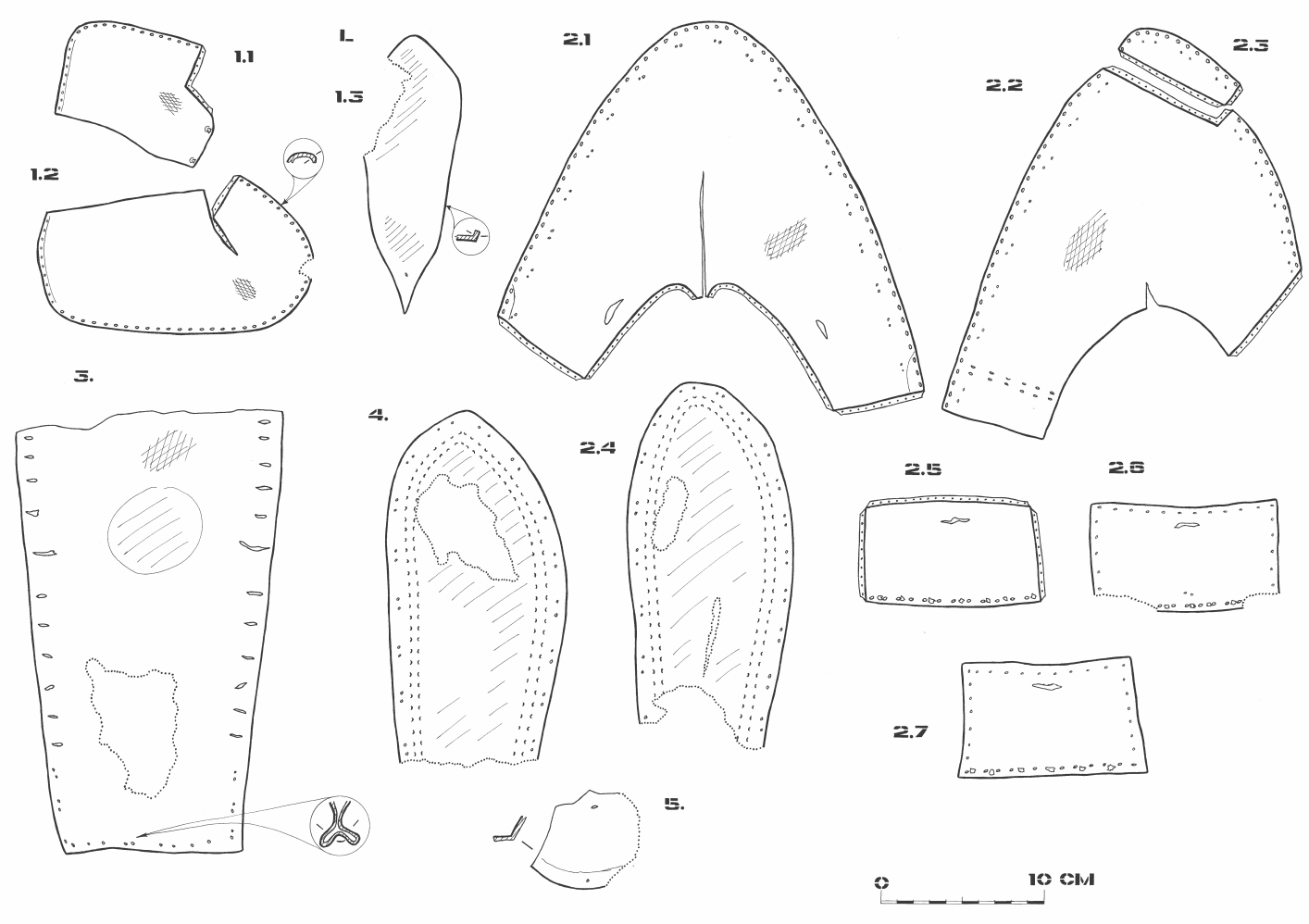

Рис. 1. Наборы и отдельные детали кожаной обуви: 1 - набор деталей мягкой туфли; 2 - набор деталей скрешня, перешитого из сапога; 3 - кожаный поршень; 4 - отдельная подошва сапога
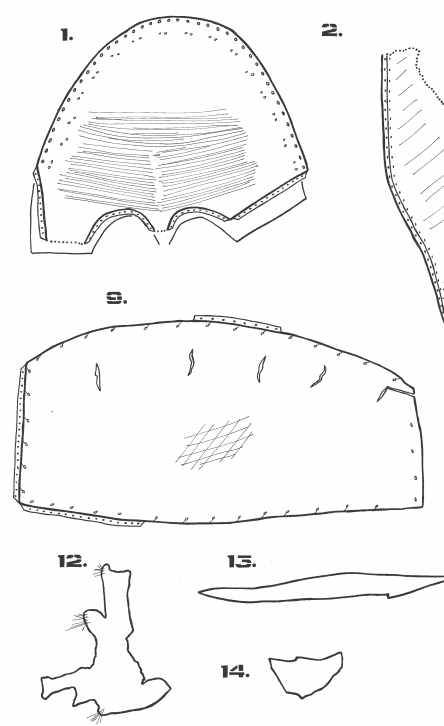

$1 \Xi$.

14.

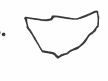

2 .

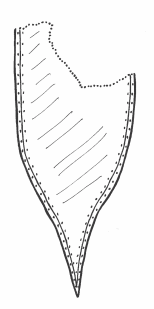

15.

s.<smiles>C1CCCCCCCCCCCCCCCC1</smiles>

s.
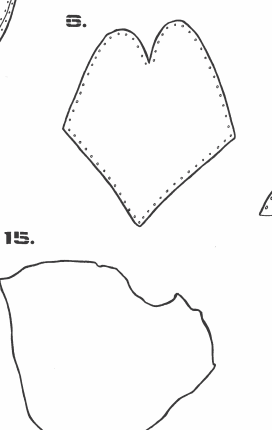

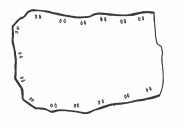

7.

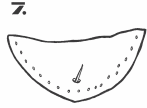

16.

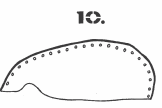

15. \{
E.

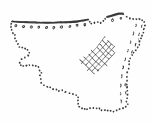

玉.
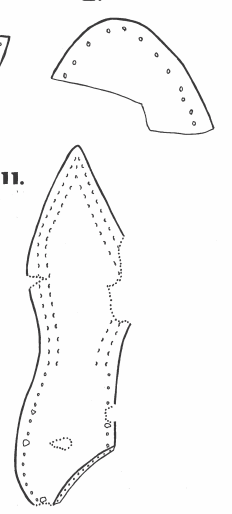

ㄴ _ _ _ $10 \mathrm{~cm}$

Рис. 2. Отдельные детали кожаной обуви и другие предметы: 1 - головка сапога с поднарядом; 2 - подошва мягкой обуви с заостренной пяткой; 3 - деталь верха обуви; 4 - заплата; 5 - деталь верха обуви с тиснением «булгари»; 6 - деталь большого пальиа рукавищьт; 7 - набор из трех подпяточных подкладок; 8 - подметка;

9 - перешитая деталь обуви (?); 10 - обрезок пятки подошвы; 11 - подошва сапога с основным швом «в подтай»; 12-16 - обрезки от раскроя 
найденный в слое щепы с навозом в шурфе 2 (№ п/ оп. 4). Набор состоял из подошвы с вытянутой пяткой и округлым носком, а также основной и дополнительной деталей верха (рис. $1: 1 ; 3$ ). Внимательный осмотр находок позволяет относить детали верха к туфле, надеваемой на правую ногу. Это определяется известной практикой раскроя средневековой обуви. Основная деталь верха имеет асимметричный крой, где боковина охватывает правую (внешнюю) сторону стопы и заходит на пятку. Дополнительная деталь верха, имеющая меньший размер, закрывает левую (внутреннюю) сторону стопы от пятки до бокового края «головки» основной детали. Сшивание бокового обреза «головки» основной детали с дополнительной деталью выполнено на левой стороне модели, т. е. на внутренней стороне обуви, которую носили на правой стопе. На выступающей части дополнительной детали имеется два отверстия для тонких ремешков-завязок с остатками самих кожаных завязок шириной 2,5 мм. Они были аккуратно обрезаны. В то же время подошва из предполагаемого набора туфли имеет сильный износ плантарной поверхности, характерный для ношения обуви на левой стопе (рис. 1: 3; каталог 1.3). Учитывая данные наблюдения, следует считать, что в культурный слой была выброшена пара изношенной обуви, с которой предварительно были аккуратно срезаны кожаные ремешки-завязки. Из слоя взяты две детали верха и подошва от разных туфель одной (?) пары. Надо полагать, что недостающие детали остались в слое, не вошедшем в площадь шурфа; 2) фрагмент подошвы из кв. 1, взятый на уровне 6 пласта в слое щепы (№ п/оп. 6). Сохранилась задняя половина с вытянутым заостренным язычком на пятке и с выраженной эксплуатационной истертостью кожи под пяткой (рис. 2: 2). Исходя из размеров сохранившейся части, подошва могла принадлежать мягкой женской обуви; 3) также к ранней группе

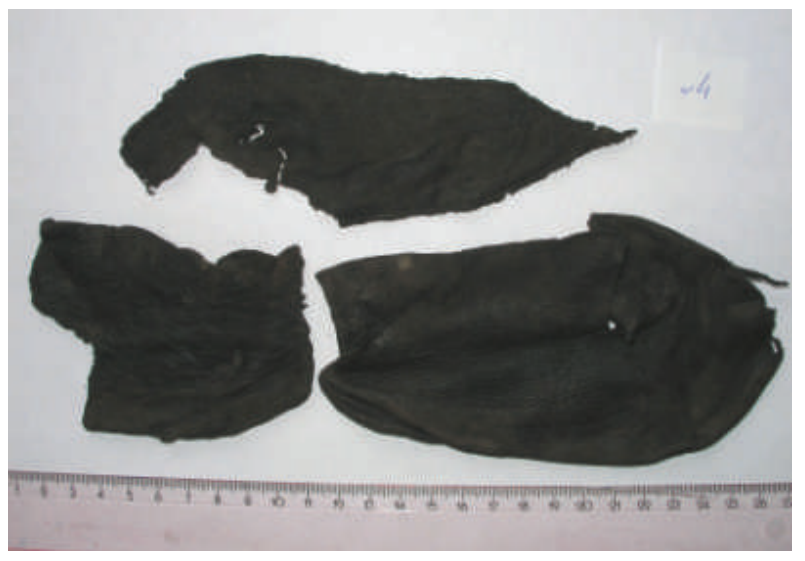

Рис. 3. Детали мягкой туфли из шурфа 2. Фото автора предметов можно отнести мелкий обрезок кожи тонкой, расслоившейся и, возможно, испытавшей нагревание (№ п/оп. 894).

Датирующими признаками являются использование тонкой кожи, вытянутая пятка подошвы, двухчастный асимметричный раскрой верха, тиснение поверхности кожи косой сеткой и отсутствие следов кожаной обшивки по верхнему краю башмака. Наиболее близкие серийные аналогии ладожским находкам показывает коллекция обуви из рва на Рюриковом городище под Новгородом, происходящая из раскопок 2001-2004 гг. Новгородская коллекция датируется в двух хронологических диапазонах широком и узком, которые определяются при сопоставлении исторического и археологического контекста. Широкий диапазон - это последняя четверть XI - первая половина XII в., а узкий - рубеж XIXII - первая треть XII в. (Курбатов, 2007. С. 103). Раскопки 2010 г. на Рюриковом городище дали возможность уточнить время засыпки рва. По мнению исследователей, окончательно ров был засыпан в самом конце XI в., накануне строительства церкви Благовещения в 1103 г. (Носов и др., 2015. C. 63). Учитывая такие технические элементы, как качество кожи, форму деталей, технику раскроя и пошива изделий, время изготовления ладожских находок следует ограничивать самыми последними годами XI в. и первыми тремя годами XII в. Также весьма вероятно, что ладожские находки были пошиты новгородским мастером.

К первой половине XVI в., а возможно к первой трети столетия, относится подошва от сапога с вытянутым заостренным носком, с основным швом «в подтай» (рис. 2: 11). Она найдена в слое щепы на уровне пласта 7 в кв. 25 (№ п/ оп. 874). По размерам подошва принадлежала подростковой обуви под стопу длиной 17-18 см. Вдоль края обуви на пятке сохранились отверстия от забитых железных гвоздей. Хронологическими индикаторами служат раскройка с выраженным расширением в пальцах и перехватом под сводом стопы, вытянутый заостренный носок, небольшая ширина стежков и короткое расстояние между ними (и то и другое по 5 мм).

К этому же времени относится головка сапога с сохранившимся полностью двухчастным поднарядом, который был вырезан из голенища сапога (рис. 2: 1; 4). Предмет зафиксирован в кв. 62 , в заполнении сруба, в слое щепы (№ п/оп. 770). Длина головки 12,2 см, ширина 16,0 см. Она имеет короткие крылья и выраженный узкий язычок на подъеме. На поверхности головки весь подъем украшен частым поперечным поверхностным линованием. В отличие от 


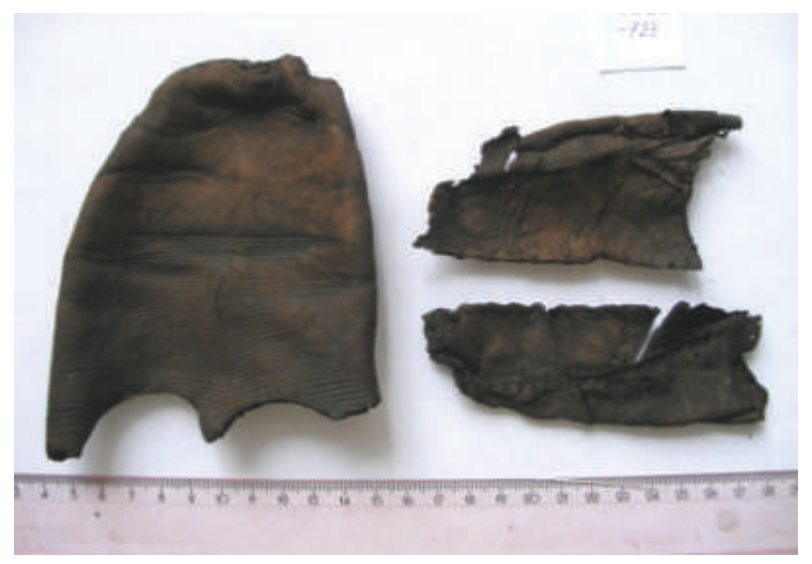

Рис. 4. Головка сапога с поднарядом (№ n/on. 770). Фото автора

глубокого поперечного тиснения головок сапог этого времени, которое было своеобразным техническим конструктивным приемом, линование служило только для декоративных целей.

Основанием для датировки этих предметов могут быть коллекции из раскопок в Ивангородской крепости (Курбатов, 1991. С. 71 сл.), на Кремлёвской площади в Вологде (Андрианова, Федоров, 2012. С. 82 сл.) и в Москве (Осипов, 2014. Илл. 21; 22).

Ко второй половине - концу XVI в. относится группа деталей обуви из заполнения деревянного сруба (колодца) в кв. 62. Это однодетальный поршень, вырезанный из голенища (?), со вторично обрезанным носком, что было сделано уже после износа поршня (рис. 1: 3). Длина сохранившейся части раскройки 25 см, максимальная ширина в носке 16,2 см, в пятке 11,0 см. При ношении пятка была стянута в складки. Обувь полностью протерта под пяткой. По боковым сторонам на расстоянии 1,3-1,6 см сделаны прорезы для кожаного ремешкаоборы шириной 0,5-0,7 см.

Здесь же встречен набор деталей скрешня - низкого рабочего башмака, перешитого из сапога (рис. 1: 2). От сапога было отрезано голенище, а для фиксации обуви на ноге служили оборы, продеваемые через два прореза на головке и один на заднике. Головка включает наружную деталь и поднаряд, а в составе задника были три слоя кожи и тонкая (0,5 см) деревянная прокладка между ними. Подошва для этого набора имеет овальную форму, без сужения в области свода стопы, со следами пришивания подметки. Подошва протерта полностью в трех местах и показывает ношение обуви на правой ноге. Парная обувь представлена в наборе отдельной подошвой, также сильно изношенной.
Основанием для датировки могут служить комплексы конца XVI в. из раскопок в Ивангородской крепости (Курбатов, 1995. С. 198 сл.) и в Москве на Манежной площади (Векслер, Осипов, 1997. С. 191 сл.). Схемы конструирования и раскройки археологических предметов из Ивангородской крепости дают представительные наборы такой обуви.

K XVIII в. можно относить один фрагмент верха обуви, встреченный в кв. 25 на уровне пласта 7, в слое щепы (№ п/оп. 852). Небольшой по размерам фрагмент $(7,5 \times 5,5$ см $)$ детали верха, предположительно головки башмака, имеет характерные признаки - равномерные сквозные округлые отверстия по краю, со стежками длиной 4 мм, с так называемым «слепым швом» вдоль другой стороны и тиснение поверхности кожи в мелкую «сеточку» (рис. 2: 5). Аналогичные формы встречены в комплексах XVIII в. при раскопках в городах Владимире-на-Клязьме и Березове в низовьях р. Оби (Курбатов, 2008; 2010). Также имеется несколько мелких фрагментов подошв и подметок, которые можно условно относить к XVI-XVII вв. (рис. 2: $6,8,9)$.

Обрезки. Встреченные восемь обрезков от первичного и вторичного раскроя имеют нестандартную форму и размеры, что определяет случайный характер их появления и вырезания непрофессиональными мастерами-кожевниками (рис. 2: 12-16).

Рукавица. Представлена раскройкой вшивной детали (рис. 2: 6) для большого пальца (№ п/оп. 1236). Изделия такого облика бытовали в русских городах на протяжении всего Средневековья и Нового времени. Признаков, уточняющих время изготовления рукавицы, на детали нет.

Заплата. Прямоугольной формы, размерами $8,5 \times 6,0$ см, нашивная заплата, найденная в кв. 25 (рис. 2: 4), имела парные сквозные отверстия шва «змейка» по трем сторонам (№ п/оп. 852). Четвертая сторона была обрезана по краю вместе со швом. Деталь, на которую нашивалась заплата, определить не представляется возможным.

Неопределенной деталью вторичного использования для XVI-XVII вв. можно считать находку в срубе колодца (рис. 2: 9). В ней можно предполагать деталь обуви, перешитую из голенища (?), размерами $23,2 \times$ 11,7 см (№ п/оп. 770). На одном торце первоначальный шов тачной и вторичный - обметочный «через край», на другом торце - сквозные отверстия отметочного шва; по длинным сторонам частично сохранились первичные швы - тачные, по всей длине имеются вторичные швы - обметочные «через край», вдоль 
одного продольного края - редкие неровные прорезы шириной 1,3-1,5 см, расстояние между ними 3,3-4,0 см; кожа плотная, КРС, толщина 1,3 мм, мерея темно-коричневая, примята, тиснение «косая сеточка».

Bblвoдbl. Небольшая коллекция кожаных предметов 2015 г., найденных на разных участках посада средневековой Ладоги, содержит предметы разных исторических периодов - от рубежа XIXII вв. до XVIII в. Это определяет перспективы археологического изучения посада на широкой площади его распространения. Появились основания считать, что хорошая сохранность органических материалов средневековой застройки и жизнедеятельности должна сохраняться в Ладоге значительно шире, чем это сейчас известно. Здесь интересно наблюдение, сделанное в других русских средневековых городах, культурный слой которых долгое время считался полностью «сухим», т. е. не сохраняющим органические остатки древней жизнедеятельности. Например, в последние десятилетия успешно исследуются средневековые культурные слои во Владимире-на-Клязьме, где сохранились участки деревянной застройки с органикой домонгольского времени, а также комплексы XIVXVI и XVIII вв., где встречены многочисленные кожаные изделия и обрезки (Осипов, 2007; Григорьев, 2008; Курбатов, 2008; Кокорина, 2015).

Археологические находки обуви и других кожаных предметов в хронологическом диапазоне от XI-XII до XVI-XVII вв. в районе Варяжской улицы позволяют снова обратиться к вопросу о развитии посадов Ладоги в позднем Средневековье. Историки рассматривали этот вопрос посредством анализа письменных документов XVI-XVII вв. и немногих известных изобразительных материалов. Для рубежа XV-XVI вв. количество дворов на посаде дают Новгородские писцовые книги, где указаны 116 дворов, в которых проживали 168 владельцев (Кирпичников, 1985. С. 172 сл.). Расчет численности семей позволяет оценить все население примерно в 650 жителей Ладожского посада на то время. Большинство горожан, видимо, занимались торговлей, рыболовством и обслуживанием речного судоходства. Указаны четыре ремесленные специальности - кожевник, портной мастер, плотник и скорняк, но это может быть неполный состав специалистов-ремесленников.

В писцовой книге Водской пятины И.В. Булгакова и П. Шипилова на 1568-1569 гг. примерно для 80\% дворовладельцев г. Ладоги указан род занятий. Здесь отчетливо видна связь занятий ладожан с р. Волховом и Ладожским озером: среди горожан названы 54 рыбных ловца, что составляет 30\% всего самодеятельного населения, и только 44 дворовладельца (23\% самодеятельного населения) занимались ремеслом. Среди них, кроме других, названы два овчинника, скорняк и четыре сапожника (Кирпичников, 2002. С. 268 сл.). Но уже на 1572 г. материалы переписи показали запустение большей части посада. Из 108 указанных в переписи тягловых дворов запустело 77, или 71\% застройки (Самоквасов, 1909. С. 303-306). К этому выводу Д.Я. Самоквасова стоит добавить, что указанные занятия отражают преимущественно не ремесло, а специализацию в сфере удовлетворения обиходных потребностей населения. Выделены четыре портных мастера, четыре сапожника, пастух, три плотника, восемь молодожников, два овчинника (Мартемьянко Ортюшин да сын его Михко), два горшечника, два гусельника, три мясника, пять хлебников и по одному - кузнец, зелейник, щепетинник, скорняк (Васка Степанов), колачник и бирич. В двух пустых дворах ранее жили портомой и скоморох. Всего названо 112 тяглых дворов и в них людей 158 человек, а пустыми названы семь «дворов» и пять «мест дворовых». Среди сапожников названы Сенка Иванов, Юшко Иванов, Ларка Иванов и Петрушка. Возможно, все трое Ивановых были родственниками (братьями) и обучались ремеслу у одного человека (Города России XVI в., 2002. С. 142-153). А в начале XVII в. в Ладоге отмечается только 16 тягловых дворов, и в дальнейшем число посадских дворов оставалось малым. По описанию 1629 г. было 49 дворов, а в 1632 г. - 19 дворов (Кирпичников, 1985. С. 180).

Занятием части населения Ладоги была местная торговля с поездками в Новгород, Тихвин, окрестные села и деревни. «В 28 день (январь) явил ладожанин Федор Синягин товару: 20 кож яловичьих и коньих, 13 опоков. Пошлины взято с четырех рублев 3 алтына 2 денги, явки 2 денги». Это записано в Таможенной книге 1625-1626 гг. таможенных голов Никиты Минина и Тимофея Пономарева новгородцам и псковичам (Дадыкина, 2012. C. 283).

Историк Н.Д. Чечулин разделял городские посады по количеству ремесленников отдельных специальностей или иным занятиям населения, отмеченным в писцовых книгах. В отдельную группу он выделил посады Каргополя, Орешка, Ладоги и Корелы XVI в., для которых занятия жителей он делил по четырем направлениям: приготовление предметов питания - 48 чел., одежды - 54 чел., предметов, необходимых в домашнем обиходе, 38 чел. и предметов, не являющихся первой необходимостью, - 51 чел. Среди них - сапожников 
13 чел., овчинников - 9 чел., скорняков - 8 чел., кожевников - 4 чел., рукавичников - 1 чел. Процент ремесленников в составе населения по этим городам значительно колеблется: в Каргополе на 1560 г. 27,3\%, в Орешке 7\%, в Ладоге 21\%, в Кореле 8,5 \%. Н.Д. Чечулин заключил, что в пограничных городах-крепостях на рубеже XVXVI вв. ремесленная деятельность была развита слабо, но это в значительной мере исправилось к середине XVI в. (Чечулин, 1889. С. 51, 52).

Таким образом, обращение к письменным документам показывает, что даже в лучшие для Ладоги годы ее единичные кожевники и сапожники, надо полагать, работали только для удовлетворения нужд самих городских жителей. В периоды же «лихолетья» своих ремесленников кожевенных специальностей в Ладоге, возможно, в отдельные годы не было совсем. Хотя сапожник упоминается в «Обыске житничного ключника Афанасия Лопухина и подъячего Юрия Юмина на Ладожском посаде о живущих дворах и рыбных ловлях» от 6 сентября 1608 г.: «У города Ладоги... да посадцкие люди... Прошка Павлов сапожник» (Селин, 2008. С. 141-143, прил. № 4).

Ранее Е.И. Оятева, рассмотрев материалы XVIXVII вв., высказалась об ограниченном характере сапожного производства в самой Ладоге, достаточном только для удовлетворения нужд собственных жителей. По ее мнению, много обуви, видимо, поступало в Ладогу из Москвы, на что указывает и наличие одинаковых клейм на подошвах (Оятева, 1965. С. 57, 58).

\section{КАТАЛОГ}

Наборы и отдельные детали кожаной обуви (puc. 1)

1. Набор (?) деталей мягкой туфли:

1.1. Дополнительная деталь верха обуви для правой стопы, размеры 9,7 × 7,3 см, подпрямоугольной формы с выступом; швы на выступе тачные, по основанию и на заднике выворотные; на углах выступа по одному отверстию с остатками кожаных ремней шириной 2,5 мм в каждом, концы ремней пришиты на бахтарме, со стороны мереи ремни аккуратно обрезаны; на верхнем крае детали нет следов пришивания кожаной обшивки, имеется одиночное круглое отверстие; кожа плотная, КРС, толщина 1,5 мм, тиснение - «сеточка»;

1.2. Основная деталь верха обуви для правой стопы асимметричная, с выделенной полуотрезом головкой; длина 16,5 cм, ширина максимальная 8,7 см, по головке 9,3 см; боковой шов тачной, по основанию и на заднике выворотные; на переднем крае отворота два отверстия 1,5 мм; кожа плотная, КРС, толщина 1,2-1,5 мм, тиснение - «сеточка»;
1.3. Подошва мягкой туфли для левой стопы: со слегка приостренным носком и вытянутой заостренной пяткой, длина полная 17,0 см, без заострения пятки 13,7 см, ширина в средней части 5,5 см, в пятке 4,2 см, полностью истерт край детали на внешней стороне стопы под пальцами; основной шов выворотный; кожа плотная, толщиной 1,31,5 мм, сильно истерта под пальцами и пяткой.

2. Набор деталей скрешня, перешитого из сапога:

2.1. Головка имеет удлиненные крылья и небольшой выступающий мысок на подъеме; длина максимальная 22,2 см, длина на подъеме 16,0 см, без мыска 15,0 см, ширина максимальная 26,5см; швы боковые и на подъеме тачные, основной выворотный, вдоль переднего края парные сквозные отверстия шва «змейка»; на оси детали вторичный разрез длиной 7,0 см, на крыльях по одному неровному прорезу длиной 1,3 и 1,9 см; кожа плотная, КРС, толщина 1,5 мм, мерея черного цвета, тиснение «сеточка»;

2.2. Поднаряд полный, имеет подшивные детали на крыле и в носке, длина 23,3 см, ширина максимальная 17,8 см; в местах пришивных деталей швы тачные, на левом крыле «слепой» шов, вдоль переднего края парные сквозные отверстия шва «змейка»; кожа плотная, КРС, толщина 1,3 мм, мерея черного цвета, тиснение «сеточка»;

2.3. Подшивная деталь поднаряда, размерами $7,5 \times 2,4$ см; швы и сама кожа аналогичны основной части поднаряда;

2.4. Подошва с основным швом «в подтай», овальной формы, без сужения в области свода стопы, сильно истерта плантарная поверхность, оборвана пятка, длина сохранившейся части 22,8 см, ширина в пальцах 10,0 см, в пятке 8,0 см; ширина захвата шва 5 мм, длина стежков 6 мм; кожа расслоилась, толщина 1,5 мм, стертость сильная; сохранился фрагмент сильно истертой подметки;

2.5.-2.7. Набор деталей задника:

2.5. Наружная деталь (задника): прямоугольная, ширина 10,7 см, высота 6,3 см; на боковых и верхнем краях швы тачные, по основанию сквозной сандальный; у верхнего края в середине горизонтальный неровный прорез длиной 1,7 см; кожа плотная, КРС, толщина 1,5 мм;

2.6. Внутренняя прокладка: прямоугольная, ширина 11,3 см, высота 6,3 см; по боковым и верхнему краям сквозные отверстия регулярного шва, по основанию сквозные отверстия сандального шва; часть нижнего края оборвана; кожа плотная, КРС, толщина 1,3 мм; изнутри к детали прилегает деревянный вкладыш, сохранившийся плохо, толщина $0,5 \mathrm{~cm}$;

2.7. Внутренняя деталь (карман задника): прямоугольная, ширина 11,2 см, высота 6,7 см; по боковым и верхнему краям сквозные отверстия регулярного 
шва, по основанию сквозные отверстия сандального шва; кожа плотная, КРС, толщина 1,3 мм.

3. Кожаный поршень: трапециевидной формы, носок обрезан, длина 26,7 см, ширина в носке 16,2 см, в пятке 11,0 см, полностью протерта под пяткой; вдоль длинных сторон на равном расстоянии, через 1,2-1,5 см, сделаны прорезы шириной 0,8-1,0 см для кожаной оборы, вероятная ширина которой составляла 0,6-0,7 см; в области пятки по краю имеются сквозные отверстия, сквозь которые продевалась толстая нить (корд), стягивавшая пятку в складку; кожа плотная, КРС, толщина 1,5 мм, мерея темнокоричневого цвета, тиснение «сеточка».

4. Подошва сапога: вероятно, парная к номеру 2.4, овальная, без сужения в области свода стопы, для правой стопы, пятка оборвана, основной шов «в подтай»; длина сохранившейся части 21,5 см, ширина под пальцами 10,5 см, в области пятки 8,4 см; плантарная поверхность сильно стерта, полностью протерта под пальцами; кожа плотная, толщина 2,0-2,2 мм.

Отдельные детали кожаной обуви и другие предметь (рuс. 2)

1. Головка сапога с поднарядом: симметричного кроя, имеет короткие боковые выступы и заостренный язычок на подъеме (оборван), длина полная 12,5 см, без язычка 11,0 cм, ширина максимальная 15,7 см; боковые швы и на подъеме тачные, основной - выворотный; на мерее поперечное частое линование; кожа КРС, плотная, толщина 1,5 мм, мерея коричневого цвета; поднаряд аналогичной формы, двухчастный, полный, выкроен из голенища сапога, из кожи МРС.

2. Подошва мягкой обуви с заостренной пяткой: сохранилась задняя половина, длина полная 16,3 см, ширина в пятке 6,7 см; основной шов тачной; кожа расслоилась, КРС, толщина 1,2 мМ, стертость средняя.

3. Деталь верха обуви: сильно фрагментирована, частично сохранились два первоначальных края, неправильной формы, размерами 10,0 × 6,5 см; один первоначальный край с выворотным швом, второй - с обметочным швом; кожа расслоившаяся, КРС, мерея черного цвета.

4. Заплата: подпрямоугольной формы, одна из коротких сторон вторично обрезана, размеры 8,5 × 5,6 см; вдоль трех сторон парные сквозные отверстия шва «змейка»; кожа плотная, КРС, толщина 1,0 мм, коричневого цвета.

5. Деталь верха обуви: сильно фрагментирована, оборвана с трех сторон; обрывок неправильной формы, размеры 7,5 × 5,5 см; на сохранившемся первоначальном крае сквозные регулярные отверстия шва, на боковой стороне сохранился «слепой шов»; кожа плотная, толщина 1,0 мм, тиснение «булгари».

6. Деталь большого пальца рукавицы: трапециевидная, с округлым вырезом на конце, размеры $11,7 \times 9,3$ см; по всем краям сквозные регулярные отверстия выворотного шва; кожа эластичная, КРС, толщина 1,1 мм.

7. Набор из трех подпяточных подкладок, общая толщина 0,5 см: наибольшая подкладка сегментовидная, полная, размерами 8,0 × 3,7 см; по внешнему краю сквозные отверстия регулярного нитяного шва, а также забивания деревянных шпеньков и железных гвоздей.

8. Подметка: фрагмент носка, размерами $8,3 \times$ 6,7 см; по краю ряд сквозных отверстий регулярного нитяного шва и следы забивания железных гвоздей; кожа плотная, КРС, толщина 1,2 мм, стертость средняя.

9. Деталь обуви (?): перешита из голенища (?), размеры 23,2 × 11,7 см; на одном торце первоначальный шов тачной и вторичный - обметочный «через край», на другом торце сквозные отверстия отметочного шва; по длинным сторонам частично сохранились первичные швы - тачные, по всей длине имеются вторичные швы - обметочные «через край», вдоль одного продольного края редкие неровные прорезы шириной 1,3-1,5 см, расстояние между ними 3,3-4,0 см; кожа плотная, КРС, толщина 1,3 мм, мерея темно-коричневая, примята, тиснение «косая сеточка».

10. Обрезок пятки подошвы: сегмент, размерами $8,9 \times 3,5$ см; по внешнему краю сквозные отверстия регулярного нитяного шва; кожа расслоилась, КРС, толщина 1,5 мм.

11. Подошва сапога с основным швом «в подтай»: имеет равномерно зауженный заостренный носок и округлую пятку, с пришивным сегментом; длина полная 21,0 см, без заостренного носка 16,5 cм, ширина в пальцах более 6,0 см, под сводом стопы 4,4 см, в пятке 5,4 см; основной шов «в подтай», ширина захвата кожи 5 мм, длина стежков 5 мм; в области пятки сквозные отверстия вертикального «сандального» шва, вдоль края неровные отверстия от железных гвоздей; кожа плотная, толщина 2,0 мм, стертость средняя, по всей поверхности, протерта под пяткой.

12. Обрезок от раскроя с края кожевого листа: неправильной формы, размерами 8,5 × 7,3 см; кожа плотная, толщиной 1,2 мм.

13. Обрезок от раскроя: узкий и длинный с заостренными концами, длиной 14,7 см, шириной 1,1 см; кожа плотная, КРС, толщиной 1,1 мм, черного цвета.

14. Обрезок от раскроя: неправильной формы, размерами 4,1 × 2,2 см; кожа плотная, КРС, толщиной 1,1 мм.

15. Обрезок от вторичного раскроя, из головки (?): неправильной формы, размерами 11,6 × 10,8 см; кожа КРС, плотная, толщиной 1,0 мм.

16. Обрезок от раскроя, с края кожевого листа: неправильной формы, размерами 10,1 × 3,0 см; кожа плотная, КРС, толщиной 1,0 мм. 


\section{Источники и литература}

Андрианова Л. С., Фёдоров А. С., 2012. Кожаная обувь из раскопок на Кремлёвской площади в Вологде // Археология Севера. Череповец. Вып. 4.

Векслер А. Г., Осипов Д. О., 1997. Кожаная обувь из раскопок на Манежной площади в Москве (по материалам 1994 г.) // Тверь, Тверская земля и сопредельные территории в эпоху Средневековья. Тверь. Вып. 2.

Города России XVI века. Материалы писцовых описаний. Подготовила Е. Б. Французова. М., 2002.

Григорьев Д. Н., 2008. Раскоп 2007 г. на Нижегородской ул. г. Владимира // Археология Владимиро-Суздальской земли. М. Вып. 2.

Дадыкина М. М., 2012. Торговые связи Тихвина и Ладоги по материалам тихвинских таможенных книг XVII в. // Староладожский сборник. СПб. Вып. 9.

Кирпичников А. Н., 1985. Посад средневековой Ладоги // Средневековая Ладога. Новые археологические открытия и исследования. Л.

Кирпичников А. Н., 2002. Ладога в третьей четверти XVI в. (первопубликация писцовой книги 1568 г.) // Ладога и ее соседи в эпоху Средневековья. СПб.

Коваль В. Ю., 2014. Ростиславль Рязанский - «малый город» средневековой Руси // Міста Давньоі Русі. Збірка наукових праць пам'яті А. В. Кузи. Киів.

Кокорина Н. А., 2015. Древнерусские кожаные изделия и обувь в коллекции археологии ВладимироСуздальского музея-заповедника // Археология Владимиро-Суздальской земли. М. Вып. 5.

Куза А. В., 1983. Социально-историческая типология древнерусских городов X-XIII вв. // Русский город (исследования и материалы). М. Вып. 6.

Куза А. В., 1985. Древнерусские поселения // Древняя Русь. Город, замок, село (Археология ССCP). M.

Куза А. В., 1989. Малые города Древней Руси. М.

Курбатов А. В., 1991. Коллекция кожаных предметов из Ивангорода (по раскопкам 1980-1986 гг.) // КСИА. Вып. 205.

Курбатов А. В., 1995. Кожаные изделия шведского периода из раскопок Ивангородской крепости // РА. № 2.
Курбатов А. В., 2007. Новгородская «революция XII века» и прогресс в кожевенном ремесле // У истоков русской государственности. К 30-летию археологического изучения Новгородского Рюрикова городища и Новгородской областной археологической экспедиции. Историко-археологический сборник: Материалы междунар. науч. конф. (Великий Новгород, 4-7 октября 2005 г.). СПб.

Курбатов А. В., 2008. Археологические данные о кожевенно-обувном ремесле в древнем Владимире // Археология Владимиро-Суздальской земли. М. Вып. 2.

Курбатов А. В., 2010. О городе Болгар и сорте кожи «булгари» // Диалог культур и народов средневековой Европы. К 60-летию со дня рождения Е. Н. Носова. СПб.

Лапшин В. А., 2018. Посад Старой Ладоги: новые исследования // Новое в археологии Старой Ладоги: материалы и исследования. СПб.

Лапшин В. А., Миляев П. А., 2018. Новые исследования на Варяжской улице в Старой Ладоге // Записки ИИМК РАН. СПб. № 19.

Носов Е. Н., Дорофеева Т. С., Хвощинская Н. В., 2015. Итоги исследования Рюрикова городища под Новгородом в 2010-2012 гг. //АО 2010-2013 годов. М.

Осипов Д. О., 2007. Обувь и другие изделия из кожи, найденные при раскопках в исторической части г. Владимира // Археология Владимиро-Суздальской земли. М. Вып. 1.

Осипов Д. О., 2014. Средневековая обувь и другие изделия из кожи (по материалам раскопок в Московском Кремле). М.

Оятева Е. И., 1965. Обувь и другие кожаные изделия Земляного городища Старой Ладоги // АСГЭ. Вып. 7.

Самоквасов Д. Я., 1909. Архивный материал: Новооткрытые документы поместно-вотчинных учреждений Московского царства. М. Т. 2.

Селин А. А., 2008. Новгородское общество в эпоху Смуты. СПб.

Чечулин Н. Д., 1889. Города Московского государства в XVI в. СПб. 